\title{
Characterization of Staphylococcus aureus Isolated from Chronically Infected Dairy Goats
}

\author{
P. Moroni, ${ }^{1}$ G. Pisoni, ${ }^{1}$ C. Vimercati, ${ }^{1}$ M. Rinaldi, ${ }^{1}$ B. Castiglioni, ${ }^{2}$ \\ P. Cremonesi, ${ }^{3}$ and P. Boettcher ${ }^{2, *}$ \\ ${ }^{1}$ Department of Animal Pathology, Hygiene and Veterinary Public Health, \\ University of Milan, via Celoria 10, 20133 Milan, Italy \\ ${ }^{2}$ Institute of Agricultural Biology and Biotechnology (IBBA), \\ National Research Council, Milan 20133, Italy \\ ${ }^{3}$ Department of Biomedical Sciences and Technologies, \\ University of Milan, Segrate, Milan, Italy
}

\section{ABSTRACT}

A herd of 88 Alpine goats in Northern Italy was monitored for a complete lactation. Milk samples were taken from each udder half during 8 monthly visits. Goats $(\mathrm{n}=28)$ with $\geq 2$ consecutive positive tests for Staphylococcus aureus in the same udder half were identified as chronically infected, and all of those had $\geq 4$ positive tests of the 8 samples. Goats with no infections in either udder half during any visit were considered healthy $(\mathrm{n}=26)$. Linear mixed models were used to examine the relationship between chronic infection by $S$. aureus and SCC and production traits. The bacteria isolated from one sample from each infected goat were genotyped on the basis of polymorphism in several genes and evaluated for the presence of genes encoding for enterotoxins. The bacteria isolated from each animal were also subject to a test for $\beta$-lactamase production and to minimum inhibitory concentration tests for 11 antimicrobial agents. As expected, SCC $\left(\log _{2}\right)$ was significantly higher in infected goats than in healthy goats (7.55 vs. 5.50). Also, mean log SCC from infected udder halves (8.02) was greater than that in uninfected udder halves from the same goats (6.44). No significant differences were observed in milk yield or for fat and protein percentages between infected and healthy goats. No genetic variability was observed among the bacteria isolated, suggesting that all were from the same strain, although isolates did vary in susceptibility to various antimicrobial agents. All $S$. aureus isolates were negative for the $\beta$-lactamase production test. The most effective drugs when tested in vitro were benzylpenicillin, amoxicillin plus clavulanic acid, cloxacillin, and cephalosporins.

Received March 8, 2005.

Accepted June 16, 2005.

Corresponding author: P. Moroni; e-mail: paolo.moroni@unimi.it.

*Present address: International Atomic Energy Agency, Wagramerstrasse 5, A-1400 Vienna, Austria.
(Key words: goat, Staphylococcus aureus, mastitis, antimicrobial susceptibility)

Abbreviation key: MLVA = multiple-locus VNTR analysis, VNTR = variable number of tandem repeats.

\section{INTRODUCTION}

For dairy producers, subclinical IMI is an important cause of poor milk quality (bacteriological quality, biochemical characteristics, and SCC). Staphylococci are the bacteria most frequently isolated from IMI in Italian dairy goat farms (Moroni et al., 2005) and, thus, are considered the most important etiological agents for mastitis (Bergonier et al., 2003). Among this group, Staphylococcus aureus is considered a major contagious pathogen. Because of its pathogenicity, S. aureus must be considered an important caprine mastitis agent because it is responsible for chronic, subclinical IMI and sometimes clinical and gangrenous mastitis, which often leads to the loss of the affected gland. Few data are available in the literature for strains of $S$. aureus isolated from dairy goats. In some early studies, $S$. aureus was isolated in a small number of subclinical IMI cases (Kalogridou-Vassiliadou, 1991; Deinhofer and Pernthaner, 1995; Contreras et al., 1997). However, in another study (da Silva et al., 2004), S. aureus was identified in $37 \%$ of the subclinical mastitis isolates. Because infected animals may pass on this microorganism in milk, they represent a source of IMI for other animals in the herd and a danger for public health. Production of enterotoxins during the manufacture and ripening of many cheeses has been studied by several researchers (Bachmann and Spahr, 1995).

The objective of this study was to examine SCC and milk quality measures of goats from a Northern Italian dairy farm; the goats were either healthy or chronically infected by $S$. aureus. In addition, the $S$. aureus isolates were characterized genotypically by multiple-locus variable numbers of tandem repeat analysis (MLVA), 
by coagulase gene RFLP analysis, and by detection of staphylococcal enterotoxin genes. These PCR-based methodologies have proven to be useful for molecular typing and epidemiological analysis of $S$. aureus isolated from human carriers (Sabat et al., 2003) and bovine mastitis (Aarestrup et al., 1995; Lange et al., 1999; Akineden et al., 2001; Sommerhäuser et al., 2003). Moreover, recent studies have shown genotypic traits of $S$. aureus strains isolated from goats and sheep (Scherrer et al., 2004). In our study, these techniques allow one to discriminate among different $S$. aureus isolates and provide information about the spread of strains within the herd. Finally, tests of antimicrobial sensitivity were applied, using 11 different antimicrobial agents.

\section{MATERIALS AND METHODS}

\section{Animals and Herd}

A total of 88 Alpine goats from a commercial dairy farm in Italy were monitored for an entire lactation (February to September 2004). The farm was free of brucellosis, tuberculosis, mycoplasmosis, and caprine arthritis-encephalitis virus after a voluntary eradication program. The farm practiced seasonal milking, and the does kidded between January and February 2004. The herd grazed on natural pastures for $6 \mathrm{~h} / \mathrm{d}$ and was supplemented with concentrates in the milking parlor (1.53 Mcal of $\mathrm{NE}_{\mathrm{L}} / \mathrm{kg}, 16 \% \mathrm{CP}$, as fed) at a flat rate of 0.5 to $1 \mathrm{~kg} / \mathrm{d}$ per doe according to lactation stage and with $0.5 \mathrm{~kg}$ of alfalfa per doe and $0.5 \mathrm{~kg}$ of alfalfa pellets per doe in the shelter. Water was available at all times. After weaning, all goats were hand-milked $2 \times /$ d without teat preparation. Neither teat dipping nor dry therapy was practiced. No clinical signs of IMI were observed for any of the goats throughout the study; thus, no mastitis therapy was administered.

\section{Milk Sampling}

Foremilk samples were obtained monthly (February to September 2004) during the usual quality test day program performed by the technicians of the Provincial Breeding Association of Asti (A.P.A. Asti). Numbered collars were used to identify each goat in the herd, and none of the animals studied had evidence of clinical mastitis at the time of sampling. Teat ends were cleaned with chlorhexidine before sampling. The first streams of foremilk were discharged, and then $10 \mathrm{~mL}$ of milk was collected aseptically from each udder half into sterile vials. Samples were kept at $4^{\circ} \mathrm{C}$ until bacteriological assays and SCC tests were performed. Samples of pooled milk (across udder halves) were tested for fat and protein concentrations (\%). Milk yield $(\mathrm{kg})$ was re- corded on the same day as the samples were collected by using recording jars in the milking parlor.

\section{Bacteriological Procedures}

Ten microliters of each milk sample was spread on blood agar plates (5\% defibrinated sheep blood). The plates were incubated aerobically at $37^{\circ} \mathrm{C}$ and examined after $24 \mathrm{~h}$. The colonies were provisionally identified on the basis of Gram stain, morphology, and hemolysis patterns. The number of each colony type was recorded. The representative colonies were then subcultured on blood agar plates and incubated aerobically at $37^{\circ} \mathrm{C}$ for $24 \mathrm{~h}$ to obtain pure cultures. Catalase and coagulase production were tested for gram-positive cocci. Specific identification of staphylococci was made using commercial micromethods (API Staph, BioMérieux, Italy). The infection status of milk samples was defined according to the procedures recommended by the National Mastitis Council (1999), and IMI was diagnosed when $>500 \mathrm{cfu} / \mathrm{mL}$ were present and when 1 to 3 colony types were isolated. Milk samples from which $>3$ colony types or $\leq 500 \mathrm{cfu} / \mathrm{mL}$ colonies of any microorganism were isolated were regarded as contaminated or uninfected, respectively, for most bacterial species. In the case of $S$. aureus, an IMI was diagnosed when 1 colony was isolated ( $\geq 100 \mathrm{cfu} / \mathrm{mL}$ ).

After monitoring the whole herd for an entire lactation, all goats (26 animals) with healthy half udders throughout the lactation and all goats (28 animals) chronically infected with $S$. aureus were chosen for statistical analyses. An animal was defined as healthy when all milk samples collected during lactation were bacteriological negative for both half udders, whereas animals chronically infected by $S$. aureus were those that had at least 1 half udder with at least 2 consecutive milk samples infected by $S$. aureus. In fact, all of the chronically infected animals had $\geq 4$ positive tests for $S$. aureus across the 8 possible sampling days in at least 1 of the udder halves. Because the precise objective of this work was to compare healthy goats to goats that were chronically infected by $S$. aureus, the data from the other 34 goats that did not fit into either chronically infected or healthy groups (as defined previously) were not included in subsequent analyses.

\section{Determination of SCC and Percentages of Protein and Fat}

For each milk sample, SCC was determined by an automated fluorescent microscopic somatic cell counter (Bentley Somacount 150, Bentley Instrument). Ethidium bromide dye was used for specific binding to the DNA in the cell nuclei. For statistical analyses, the 
SCC were converted to SCS using the standard $\log _{2}$ transformation of Ali and Shook (1980). Percentages of milk fat and protein were determined on composite milk samples and assayed by an automated Fourier transformed infrared absorption spectrophotometric analyzer (Milkoscan, Foss, Hillerød, Denmark).

\section{Genotypic Characterization}

Twenty-eight $S$. aureus isolates from different animals with chronic infection throughout the lactation were frozen and stored at $-70^{\circ} \mathrm{C}$ in a nutrient broth enriched with $15 \%$ glycerol until DNA extraction could be performed. Briefly, for the molecular assay, the nucleic acids were extracted from $1 \mathrm{~mL}$ of bacterial suspension using the PUREGENE DNA Purification Kit (Gentra Systems, Minneapolis, MN) according to the recommendation of the manufacturer for gram-positive bacteria. The isolates were identified as $S$. aureus by amplification of a $S$. aureus-specific section of the $23 \mathrm{~S}$ rRNA gene using conventional, previously described PCR methods (Straub et al., 1999).

The amplification of variable number of tandem repeats (VNTR) loci, including clfA, clfB, sdr, spa, and ssp genes, was carried out by a PCR assay using the protocol described by Sabat et al. (2003) with slight modifications. Briefly, we used the following conditions: a 5-min precycle at $94^{\circ} \mathrm{C}$, then 30 times the following sequence $\left(30 \mathrm{~s}\right.$ at $94^{\circ} \mathrm{C}, 30 \mathrm{~s}$ at $55^{\circ} \mathrm{C}$, and $30 \mathrm{~s}$ at $\left.72^{\circ} \mathrm{C}\right)$, followed by final extension incubation at $72^{\circ} \mathrm{C}$ for $7 \mathrm{~min}$. The PCR products were analyzed on a $4 \%$ agarose gel (GellyPhor, Euroclone, Milan, Italy) stained with ethidium bromide $(0.05 \mu \mathrm{g} / \mu \mathrm{L}$; Sigma Aldrich, Milan, Italy).

To detect the polymorphic region of the coagulase gene (coa), a PCR assay was performed as described by Hookey et al. (1998). For the restriction endonuclease analysis, approximately $300 \mathrm{ng}(12 \mu \mathrm{L})$ of PCR products were digested at $37^{\circ} \mathrm{C}$ for $2 \mathrm{~h}$ with $1 \mathrm{U}$ of the restriction endonuclease $A l u \mathrm{I}$ (New England BioLabs) according to the manufacturer's instructions. All of the digested PCR products were analyzed on a $4 \%$ agarose gel (GellyPhor) stained with ethidium bromide $(0.05 \mu \mathrm{g} / \mu \mathrm{L})$. The reference strain ATCC 25923 was included in both PCR assays as positive control.

The PCR products of the coa gene of 6 representative isolates were sequenced by CRIBI Services (CRIBI, Padova, Italy) on an ABI377 sequencer by using the ABI PRISM dye-terminator cycle sequencing ready reaction kit with Amplitaq DNA polymerase (Perkin-Elmer, Boston, MA; Applied Biosystems, Foster City, CA).

The isolates were also analyzed to detect the enterotoxin genes, including sea, sec, sed, seg, seh, sei, sej, and sel. Staphylococcal enterotoxin genes were detected by multiplex PCR assay as described by Cremonesi et al.
(2005). The PCR products were analyzed on a $2 \%$ agarose gel (GellyPhor) stained with ethidium bromide (0.05 $\mu \mathrm{g} / \mu \mathrm{L})$. The reference strain ATCC 700699 harboring sea, sec, seg, sei, and sel genes (Letertre et al., 2003) was included as positive for the multiplex PCR assay.

\section{MIC Tests}

The $S$. aureus (28 isolates) isolated from different animals with chronic infection throughout the lactation were tested for antimicrobial susceptibility. The antibiotics selected for the study were benzylpenicillin, ampicillin, amoxicillin, amoxicillin plus clavulanic acid, cloxacillin, cephalonium, cephoperazone, oxytetracycline, doxycycline, kanamycin, and lincomycin. They were provided in powder form by the respective manufacturers. The antibiotics were dissolved in suitable solvents to make stock solutions and then diluted in sterile distilled water according to the methods recommended by the National Committee for Clinical Laboratory Standards (NCCLS, 2002). Minimum inhibitory concentration tests were performed according to the microdilution broth method as recommended by the NCCLS (2002) using 96-well microtiter plates. Serial 2-fold dilutions of the antimicrobial agents were prepared starting from the stock solution of each drug. The dilution schemes differed according to the antibiotic. Inoculates were prepared by diluting an overnight Mueller-Hinton broth culture in buffered saline solution to a density of 0.5 on the McFarland turbidity scale and finally diluting again 40 -fold before testing. The MIC was defined as the lowest concentration of antibiotic at which bacterial growth was completely inhibited. A reference strain of S. aureus (ATCC 29213) was inoculated as a control on each plate. The MIC data were summarized by calculating the MIC value for which 50 and $90 \%$ of the isolates were equal to or below (i.e., $\mathrm{MIC}_{90}=\mathrm{MIC}$ required to inhibit growth for $90 \%$ of the isolates tested and $\mathrm{MIC}_{50}=$ MIC required to inhibit 50\% of the isolates tested), as well as the range of MIC values required to prevent growth of any (minimum) and all (maximum) isolates. Moreover, the $S$. aureus isolates were tested for $\beta$-lactamase production by the nitrocefin test (Dry Slide Nitrocefin, Difco Laboratories, Franklin Lakes, NJ).

\section{Statistical Analyses}

Two types of statistical analyses were applied, both by using the procedure MIXED of SAS (Cary, NC). In the first analysis, the relationship between infection status and SCS was examined. For this study, SCS was available for each udder half, and the data set for analysis included 841 records, 404 from healthy animals and 437 from animals with chronic IMI of $S$. 
aureus. Each of the 54 animals had either 7 or 8 records. The model equation for the analysis was

$$
\begin{aligned}
\mathrm{y}_{\mathrm{ijklm}}= & \text { day }_{\mathrm{i}}+\text { par }_{\mathrm{j}}+\inf _{\mathrm{k}}+\text { day } \times \inf _{\mathrm{ik}} \\
& + \text { goat }_{\mathrm{kl}}+\operatorname{half}_{\mathrm{lm}}+\mathrm{e}_{\mathrm{ijklm}}
\end{aligned}
$$

where $\mathrm{y}_{\mathrm{ijk}}$ is the observed value for the SCS obtained on sample day $i$ from udder half $m$ of goat $l$ with infection status $k, d_{i}$ is the fixed effect of sample day $i(i=$ 1 to 8 ), $\operatorname{par}_{\mathrm{j}}$ is the fixed effect of parity $\mathrm{j}$ ( $\mathrm{j}=1$ to 6$), \inf _{\mathrm{k}}$ is the fixed effect of infection status $(\mathrm{k}=1$ for healthy or 2 for chronically infected with $S$. aureus), day $\times$ inf $_{\text {ik }}$ is the fixed effect of the interaction between infection status and sample date, goat $t_{\mathrm{kl}}$ is the random effect of goat 1 nested within infection status $\mathrm{k}$, half $f_{\mathrm{m}}$ is the random effect of udder half $m$ of goat $l$ (goat and udder half effects were included to account for repeated observations), and $\mathrm{e}_{\mathrm{ijkl}}$ is the random residual.

The infection status was defined in 2 ways, and a separate analysis was applied for each. The first definition was made on an animal basis (i.e., healthy or chronically infected) and applied to all observations from both udder halves for a given goat. The second definition was on the basis of the individual udder halves at the time of the sample and included 4 categories. One category simply included all records from goats that remained uninfected throughout the study (i.e., $\mathrm{n}=404$ ), whereas 3 new categories were established for records from the chronically infected goats. The first of these groups consisted of records from the udder halves (of infected goats) that had been free of IMI up to the sample date $(n=71)$. These data included all records from the healthy udder half of 8 infected (in the other udder half) goats that remained uninfected throughout the study, plus the early lactation records from udder halves of 10 goats that became infected (in that other half) on a later sample date. The second group consisted of records from udder halves that were uninfected at the time of the sample, but had been infected at some other previous sample date $(\mathrm{n}=97)$, and the third category consisted of records from quarters that were infected at the time of sampling $(\mathrm{n}=269)$. The goals of this second definition were to test whether IMI by $S$. aureus in one udder half of a given goat was associated with increased SCS in the other uninfected udder half and if the presence of $S$. aureus in an udder half at a given point in a lactation was associated with increased SCS during later times when $S$. aureus was no longer detectable. Least squares means were obtained for each category of infection status in the 2 analyses and compared (within analysis) for significant differences among categories.

The second analysis tested the relationship between chronic IMI by $S$. aureus and the recorded milk produc- tion traits (yields of milk, fat, and protein along with fat and protein percentages). Only one observation was available per goat per sample day for these traits, and the data included 416 observations (202 from healthy and 214 from infected animals) for each trait. The model for this set of analyses was simpler than for that for SCS (equation [1]). First, production traits were based on total production of both udder halves, so the effect of udder half was not included in the model. Second, the interaction of sample day and infection status was not included because preliminary analyses indicated that the effect had low significance. Third, only the single animal-based definition of infection status was testable. The effect of infection status was of primary interest in this analysis, and least squares means were calculated for healthy and infected animals and tested for significant differences. Infection status was defined 2 ways, and separate analyses were run for each. The first analysis was to test for the general effect of infection by $S$. aureus on production, and animals were considered healthy or infected. The second analysis considered whether animals were infected in one or both udder halves. For this analysis, 3 groups were defined: 1) healthy $(n=202), 2)$ unilaterally infected $(n=122)$, and 3 ) bilaterally infected $(n=92)$.

\section{RESULTS AND DISCUSSION}

\section{Bacteriological Analyses}

A total of 1367 aseptic foremilk samples were collected from both half udders of 88 lactating goats. The prevalence of infection was $50.2 \%(\mathrm{n}=686)$ of all samples examined. Among goats with IMI, $52.3 \%$ had unilateral infection; the others had both udder halves infected. The most prevalent mastitis agents were coagulase-negative staphylococci at $23.4 \%$ ( $n=320$ samples). Environmental pathogens (Streptococcus spp. and coliforms) were isolated from 82 milk samples; none had a prevalence of $>4 \%$. Neither Salmonella spp. nor Listeria monocytogenes were detected.

Staphylococcus aureus was in $20.8 \%(\mathrm{n}=284)$ of milk samples and was the second most common pathogen isolated. Twenty-eight goats were chronically infected throughout lactation with at least 2 consecutive isolations of $S$. aureus (Table 1).

\section{Staphylococcus aureus and SCS and Production Traits}

All factors included in equation [1] had significant $(P$ $<0.05)$ effects on SCS. Repeatability of SCS from the same udder half across the lactation was 0.52 . Of primary interest, however, were the differences in SCS 
Table 1. Isolation of Staphylococcus aureus (X) from left (L) and right (R) half udders in 28 goats chronically infected during 8 mo of lactation.

\begin{tabular}{|c|c|c|c|c|c|c|c|c|c|}
\hline \multirow[b]{2}{*}{ Goat } & \multirow[b]{2}{*}{ Side } & \multicolumn{8}{|c|}{ Month } \\
\hline & & 1 & 2 & 3 & 4 & 5 & 6 & 7 & 8 \\
\hline 224 & $\begin{array}{l}\mathrm{L} \\
\mathrm{R}\end{array}$ & $\mathrm{X}$ & $\begin{array}{l}X \\
X\end{array}$ & $\mathrm{X}$ & $\mathrm{X}$ & $\mathrm{X}$ & $\mathrm{X}$ & $\mathrm{X}$ & $\mathrm{X}$ \\
\hline \multirow[t]{2}{*}{225} & $\mathrm{~L}$ & & $\mathrm{X}$ & & & & & & \\
\hline & R & $\underset{\mathrm{X}}{\mathrm{X}}$ & $\mathrm{X}$ & $\mathrm{X}$ & $\underset{\mathrm{y}}{\mathrm{X}}$ & $\mathrm{X}$ & $\mathrm{Y}$ & $\underset{\mathrm{y}}{\mathrm{X}}$ & $\begin{array}{l}\mathrm{X} \\
\mathrm{X}\end{array}$ \\
\hline 236 & $\begin{array}{l}L \\
R\end{array}$ & $x$ & $x$ & $x$ & $x$ & $x$ & $x$ & $x$ & $X$ \\
\hline 244 & $\begin{array}{l}\mathrm{L} \\
\mathrm{R}\end{array}$ & $\mathrm{X}$ & $\mathrm{X}$ & $\mathrm{X}$ & & $\mathrm{X}$ & $\mathrm{x}$ & $\mathrm{X}$ & \\
\hline 245 & $\begin{array}{l}\mathrm{L} \\
\mathrm{R}\end{array}$ & $\mathrm{X}$ & & $\mathrm{X}$ & $\mathrm{X}$ & & $\mathrm{X}$ & $\mathrm{X}$ & $\mathrm{X}$ \\
\hline 250 & ${ }_{\mathrm{R}}$ & $\begin{array}{l}\mathrm{X} \\
\mathrm{X}\end{array}$ & $\begin{array}{l}\mathrm{X} \\
\mathrm{X}\end{array}$ & $\mathrm{X}$ & $\mathrm{X}$ & $\mathrm{X}$ & $\mathrm{x}$ & $\begin{array}{l}\mathrm{X} \\
\mathrm{X}\end{array}$ & \\
\hline \multirow{2}{*}{251} & $\mathrm{~L}$ & $\hat{x}$ & $\hat{x}$ & $\mathrm{X}$ & $\mathrm{X}$ & $\hat{x}$ & $\mathrm{X}$ & $\hat{x}$ & $\mathrm{X}$ \\
\hline & $\mathrm{R}$ & $\mathrm{x}$ & $\mathrm{X}$ & $\mathrm{x}$ & $\mathrm{X}$ & $\mathrm{x}$ & $\mathrm{X}$ & $\mathrm{X}$ & $\mathrm{X}$ \\
\hline \multirow[t]{2}{*}{270} & $\mathrm{~L}$ & $\mathrm{X}$ & $\mathrm{X}$ & $\mathrm{X}$ & $\mathrm{X}$ & $\mathrm{X}$ & $\mathrm{X}$ & $\mathrm{X}$ & $\mathrm{X}$ \\
\hline & $\mathrm{R}$ & $\mathrm{X}$ & $\mathrm{X}$ & $\mathrm{X}$ & $\mathrm{X}$ & $\mathrm{X}$ & $\mathrm{X}$ & $\mathrm{X}$ & $\mathrm{X}$ \\
\hline 277 & $\begin{array}{l}\mathrm{L} \\
\mathrm{R}\end{array}$ & $\mathrm{X}$ & $\mathrm{X}$ & & $\mathrm{X}$ & $\mathrm{X}$ & $\mathrm{X}$ & $\mathrm{X}$ & \\
\hline \multirow[t]{2}{*}{293} & $\mathrm{~L}$ & $\mathrm{X}$ & $\mathrm{X}$ & $\mathrm{X}$ & $\mathrm{X}$ & $\mathrm{X}$ & $\mathrm{X}$ & $\mathrm{X}$ & $\mathrm{X}$ \\
\hline & $\mathrm{R}$ & & $\mathrm{X}$ & $\mathrm{X}$ & $\mathrm{X}$ & $\mathrm{X}$ & $\mathrm{x}$ & $\mathrm{X}$ & $\mathrm{x}$ \\
\hline 296 & $\mathrm{~L}$ & $x$ & $\mathrm{X}$ & $\mathrm{X}$ & $\mathrm{X}$ & $\mathrm{X}$ & $\mathrm{x}$ & $\underset{\mathrm{y}}{\mathrm{X}}$ & \\
\hline \multirow[t]{2}{*}{297} & $\begin{array}{l}n \\
\mathrm{~L}\end{array}$ & $\hat{x}$ & $\hat{x}$ & $\mathrm{X}$ & $x$ & $x$ & $\hat{X}$ & $\begin{array}{l}\Lambda \\
X\end{array}$ & $\mathrm{x}$ \\
\hline & $\mathrm{R}$ & $\mathrm{X}$ & $\mathrm{X}$ & $\mathrm{X}$ & $\mathrm{X}$ & & & $\mathrm{x}$ & \\
\hline \multirow[t]{2}{*}{299} & $\mathrm{~L}$ & $\mathrm{x}$ & $\mathrm{X}$ & $\mathrm{X}$ & & & & $\mathrm{X}$ & \\
\hline & $\mathrm{R}$ & & $\mathrm{X}$ & & $\mathrm{X}$ & $\mathrm{X}$ & $\mathrm{X}$ & $\mathrm{X}$ & $\mathrm{X}$ \\
\hline \multirow[t]{2}{*}{303} & $\mathrm{~L}$ & X & $\mathrm{X}$ & & $\mathrm{X}$ & $\mathrm{X}$ & $\mathrm{X}$ & & $\mathrm{X}$ \\
\hline & $\mathrm{R}$ & & $\mathrm{X}$ & $\mathrm{X}$ & $\mathrm{X}$ & & $\mathrm{X}$ & $\mathrm{X}$ & $\mathrm{X}$ \\
\hline \multirow[t]{2}{*}{312} & $\mathrm{~L}$ & $\mathrm{X}$ & $\mathrm{X}$ & $\mathrm{X}$ & $\mathrm{X}$ & $\mathrm{X}$ & $\mathrm{x}$ & $\mathrm{x}$ & $\mathrm{X}$ \\
\hline & $\mathrm{R}$ & $\mathrm{X}$ & $\mathrm{X}$ & $\mathrm{X}$ & $\mathrm{X}$ & $\mathrm{X}$ & $\mathrm{X}$ & $\mathrm{X}$ & $\mathrm{X}$ \\
\hline 317 & $\mathrm{~L}$ & $\mathrm{x}$ & $\mathrm{X}$ & $\mathrm{X}$ & $\mathrm{X}$ & $\mathrm{X}$ & $\mathrm{x}$ & $\mathrm{x}$ & \\
\hline \multirow[t]{2}{*}{319} & $\mathrm{~L}$ & $\mathrm{x}$ & $\mathrm{X}$ & $\mathrm{X}$ & $\mathrm{x}$ & $\mathrm{X}$ & $\mathrm{x}$ & $\mathrm{x}$ & $\mathrm{X}$ \\
\hline & $\begin{array}{l}\mathrm{R} \\
\mathrm{L}\end{array}$ & $\mathrm{x}$ & $\mathrm{X}$ & $\mathrm{X}$ & & & & $\mathrm{X}$ & $\mathrm{x}$ \\
\hline 348 & $\mathrm{R}$ & & $\mathrm{X}$ & $\mathrm{X}$ & & & & & \\
\hline 460 & $\mathrm{~L}$ & $\mathrm{X}$ & $\mathrm{X}$ & $\mathrm{X}$ & & & $\mathrm{X}$ & $\mathrm{X}$ & $\mathrm{X}$ \\
\hline & $\mathrm{R}$ & $\mathrm{X}$ & & $\mathrm{X}$ & $\mathrm{X}$ & $\mathrm{X}$ & & & $\mathrm{X}$ \\
\hline 467 & $\mathrm{~L}$ & $\mathrm{X}$ & $\mathrm{X}$ & $\mathrm{X}$ & $\mathrm{X}$ & $\mathrm{X}$ & $\mathrm{x}$ & $\mathrm{X}$ & $\mathrm{X}$ \\
\hline 473 & $\mathrm{R}$ & & & & & & & & \\
\hline & $\mathrm{R}$ & $\mathrm{X}$ & $\mathrm{X}$ & $\mathrm{X}$ & & & & $\mathrm{X}$ & \\
\hline 479 & $\mathrm{~L}$ & $\mathrm{X}$ & $\mathrm{X}$ & $\mathrm{X}$ & & & & $\mathrm{X}$ & \\
\hline & $\mathrm{R}$ & $\mathrm{X}$ & & $\mathrm{X}$ & $\mathrm{X}$ & & & & \\
\hline 480 & $\mathrm{~L}$ & & $\mathrm{X}$ & & & $\mathrm{X}$ & & & $\mathrm{X}$ \\
\hline & $\mathrm{R}$ & $\mathrm{X}$ & $\mathrm{X}$ & $\mathrm{X}$ & $\mathrm{X}$ & & $\mathrm{X}$ & $\mathrm{X}$ & $\mathrm{X}$ \\
\hline 521 & $\mathrm{~L}$ & $\mathrm{X}$ & $\mathrm{X}$ & $\mathrm{X}$ & $\mathrm{X}$ & $\mathrm{X}$ & $\mathrm{x}$ & $\mathrm{X}$ & $\mathrm{X}$ \\
\hline & $\mathrm{R}$ & X & & & & & & & \\
\hline $244 \mathrm{~b}$ & $\begin{array}{l}\mathrm{L} \\
\mathrm{R}\end{array}$ & $\mathrm{X}$ & $\mathrm{X}$ & $\mathrm{X}$ & $\mathrm{X}$ & & $\mathrm{X}$ & $\mathrm{X}$ & $\begin{array}{l}\mathrm{X} \\
\mathrm{X}\end{array}$ \\
\hline $251 \mathrm{~b}$ & $\mathrm{~L}$ & $\mathrm{X}$ & & $\mathrm{X}$ & $\mathrm{X}$ & $\mathrm{X}$ & $\mathrm{X}$ & $\mathrm{X}$ & $\mathrm{X}$ \\
\hline & $\mathrm{R}$ & & $\mathrm{X}$ & $\mathrm{X}$ & & & $\mathrm{X}$ & $\mathrm{X}$ & \\
\hline $297 \mathrm{~b}$ & $\mathrm{~L}$ & $\mathrm{X}$ & $\mathrm{X}$ & $\mathrm{X}$ & $\mathrm{X}$ & & $\mathrm{X}$ & $\mathrm{X}$ & \\
\hline & $\mathrm{R}$ & $\mathrm{X}$ & $\mathrm{X}$ & $\mathrm{X}$ & $\mathrm{X}$ & & & $\mathrm{X}$ & \\
\hline $312 \mathrm{~b}$ & $\mathrm{~L}$ & $\mathrm{X}$ & $\mathrm{X}$ & $\mathrm{X}$ & $\mathrm{X}$ & & & & \\
\hline & $\mathrm{R}$ & $\mathrm{X}$ & $\mathrm{X}$ & $\mathrm{X}$ & & & $\mathrm{X}$ & & \\
\hline
\end{tabular}

according to infection status. Least squares means for the different infection categories are shown in Table 2 for both definitions of infection status. When the comparison was made on an animal basis (analysis 1) the animals with chronic IMI by $S$. aureus had much higher
SCS than did the healthy animals $(P<0.0001)$. The difference between categories was approximately 2 SCS (2.05). Inasmuch as SCS was based on a $\log _{2}$ transformation of SCC, this result means that the SCC of animals infected by $S$. aureus averaged approximately 4 
Table 2. Least squares means of 841 monthly measurements ${ }^{1}$ of $\mathrm{SCS}^{2}$ in milk from each udder half of 26 healthy goats and 28 goats chronically infected with Staphylococcus aureus (Analysis 1) and from udder halves with different infection statuses and infection histories (Analysis 2),

\begin{tabular}{lrrr}
\hline Infection status & $\mathrm{n}$ & $\mathrm{LSM}$ & SEM \\
\hline Analysis 1 & & & \\
$\quad$ Healthy & 404 & $5.50^{\mathrm{a}}$ & 0.18 \\
$\quad$ Chronically infected & 437 & $7.55^{\mathrm{b}}$ & 0.17 \\
Analysis 2 & & & \\
$\quad$ Uninfected goat & 404 & $5.48^{\mathrm{a}}$ & 0.16 \\
$\quad$ Uninfected udder half, infected goat & \\
$\quad$ Pathogen-free sample, infected udder half & 41 & $6.40^{\mathrm{b}}$ & 0.25 \\
$\quad$ Infected sample & 97 & $7.19^{\mathrm{c}}$ & 0.23 \\
& 269 & $8.02^{\mathrm{d}}$ & 0.17 \\
\hline
\end{tabular}

a,b,c,d Least squares means from the same analysis with different superscripts are different $(P<0.03)$.

${ }^{1}$ Seven or 8 measurements per udder half across a lactation.

${ }^{2} \log _{2}$ transformation.

${ }^{3}$ Chronically infected in other udder half.

${ }^{4}$ Infected at some point in the same lactation, but not on the sample date.

times the level of SCC in healthy animals. The difference in SCS among healthy goats and those infected by $S$. aureus observed in this study was much greater than between healthy udder halves and those infected by coagulase-negative staphylococci (SCS $=0.78$ ), as observed in a previous study in Italian goats (Moroni et al., 2005). Similar results were also reported by Leitner et al. (2004), based on a study of goats in Israel. This combination of results suggest that $S$. aureus causes a much greater immune response and could potentially lead to more damage to the udder tissue.

Clear differences between types of $S$. aureus infections were observed when infection status was defined more precisely (analysis 2 of Table 2). The lowest SCS (5.48) was observed among udder halves of completely healthy animals. Infections in one udder half seemed to have systemic effects causing elevated SCS in the other, uninfected udder half, as the SCS in such cases was nearly one SCS greater than that from healthy animals, in agreement with the results of Dulin et al. (1983). This result differs from that observed by Davis et al. (2004) in dairy cattle, where no increase in SCS was observed in healthy quarters of infected cows. However, animals in that study were intentionally infected with Streptococcus uberis rather than S. aureus. In this study, infections by $S$. aureus seemed to have lingering effects on the immune status of udder halves even after the pathogen was eliminated (or at least undetectable in milk), because the mean SCS from this type of udder half was $>1.5$ SCS higher than in udder halves that had not been infected in the current lactation. The greatest SCS (8.02) was observed in udder halves with active infections. This value was $>2.5$ SCS greater than for uninfected goats.
Table 3. Least squares means of 416 monthly measurements ${ }^{1}$ of milk production traits for 26 healthy goats and 28 goats chronically infected with Staphylococcus aureus. Standard errors of the LSM are presented in parentheses.

\begin{tabular}{lllc}
\hline & Healthy & Infected & Difference $^{2}$ \\
\hline Milk, kg & $2.29(0.10)$ & $2.15(0.11)$ & 0.14 \\
Fat, kg & $0.078(0.003)$ & $0.075(0.004)$ & 0.003 \\
Protein, kg & $0.071(0.003)$ & $0.066(0.003)$ & 0.005 \\
Fat, \% & $3.64(0.12)$ & $3.65(0.12)$ & -0.01 \\
Protein, \% & $3.19(0.04)$ & $3.17(0.04)$ & 0.02 \\
\hline
\end{tabular}

${ }^{1}$ Seven or 8 measurements per goat across a lactation.

${ }^{2}$ None of the differences were significant $(P>0.34)$.

Table 3 has the least squares means for the production traits for healthy and chronically infected (with $S$. aureus) goats. No effect of $S$. aureus infection was observed, as none of the means for any trait were significantly different between the 2 infection statuses. In addition, no significant differences were observed when lateral or bilateral infection was considered (thus, no table was created). The least squares mean for milk yield was numerically greater for unilaterally infected goats $(2.25 \mathrm{~kg})$ than for bilaterally infected goats $(2.01$ $\mathrm{kg}$ ), but this difference was not statistically significant. These results seem to suggest that although infection by $S$. aureus has the potential to lead to damage to the secretory tissue of the udder, no effect was observed in the concurrent lactation. Perhaps such effects, assuming they occur, may be manifested in lower production in a subsequent lactation.

\section{Genetic Characterization}

The isolates were subtyped on the basis of the PCRamplicons fragment sizes. Amplification by multiplex PCR of clfA, clfB, spa, and ssp genes resulted in a single amplicon with the same size for all $28 \mathrm{~S}$. aureus isolates, respectively, of approximately 1013, 930, 90, and 180 $\mathrm{bp}$, and amplification of the $s d r$ gene resulted in 2 fragments with the same sizes for all 28 isolates (approximately 550 and $750 \mathrm{bp}$ ) (Figure 1A). Amplification of the coagulase gene resulted in a single amplicon (760 $\mathrm{bp}$ ), and digestion with $\mathrm{AluI}$ yielded identical restriction profiles for all of the strains examined (Figure 1B). All of the $S$. aureus isolates harbored sec and sel genes (Figure 1C).

Tenover et al. (1995) defined as "genetically related isolates" (clones) those isolates that are indistinguishable from each other by a variety of genetic tests: identification of clones is based on monitoring of multiple genetic markers of sufficient discriminatory power. As described by Sabat et al. (2003), the MLVA system has proven to have a satisfactory discrimination ability and reproducibility for epidemiological surveys of $S$. aureus 

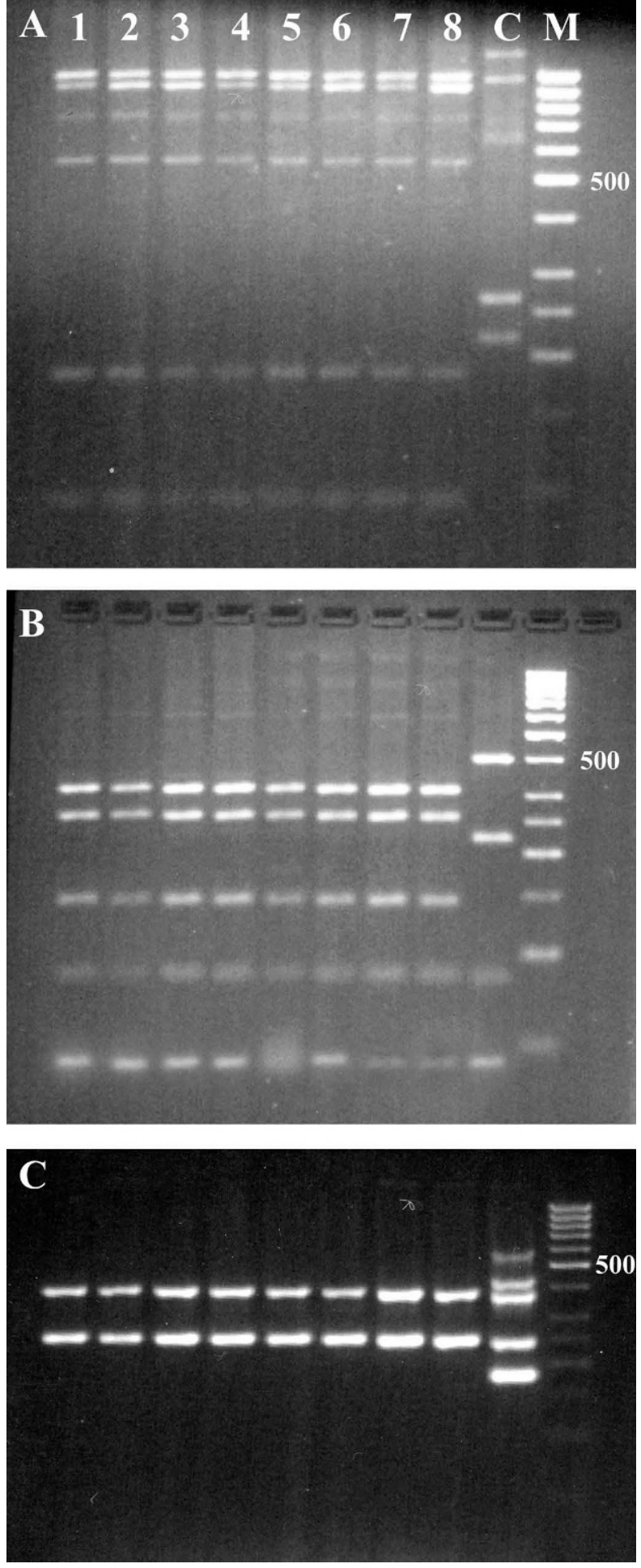

Figure 1. Agarose gel electrophoresis of PCR products of 8 representative Staphylococcus aureus isolates (lanes 1 to 8). A) Multiplelocus variable numbers of tandem repeat analysis patterns: clfA (1013 bp), clfB (930 bp), sdr (750 and $550 \mathrm{bp})$, ssp (180 bp), spa (90 bp); B) RFLP patterns of the coagulase gene digested with AluI; and C) PCRamplified toxin genes sec $(371 \mathrm{bp})$ and sel $(240 \mathrm{bp})$. Lane $\mathrm{C}$ is the positive control, and Lane M is the 50-bp DNA ladder (Finnzymes, Espoo, Finland). and seems to be, at the very least, comparable with any other high-discriminatory power DNA-based method (e.g., PFGE or ribotyping) applied currently for $S$. aureus typing. Moreover, in our study we tested all of the isolates also for PCR RFLP analysis of the coagulase gene, a method previously used for typing $S$. aureus isolates from cattle, goats, and sheep (Aarestrup et al., 1995; Akineden et al., 2001; Scherrer et al., 2004).

According to observed gene polymorphisms, RFLP patterns of the coagulase gene, and toxin patterns, a single bacterial clone seemed to be responsible for the cases of IMI in this herd. Predominance of a single clone is likely to be the result of contagious spread.

The RFLP patterns of 6 isolates, selected on the basis of the different antimicrobial resistance phenotypes (see Table 4: isolate numbers $6,8,19,22,24$, and 27), were substantiated by the analysis of nucleotide sequences. Association between RFLP and sequence analysis of the polymorphic region of coa gene allows one to determine whether strains with identical AluI patterns have identical nucleotide sequences, thus increasing the discriminatory power (Schwarzkopf and Karch, 1994; Hookey et al., 1998; Shopsin et al., 2000). The sequence analysis confirmed that the $A l u I$ recognition sites were conserved among isolates and that the sequences of the coa polymorphic region were found to have $100 \%$ nucleotide identity (data not shown) across all isolates.

The size of the polymorphic region of the coa gene and the presence of the gene encoding for sec in the isolates of $S$. aureus collected from goat's milk are in agreement with previous studies (Scherrer et al., 2004). In other studies, sec producers were described as the most prevalent enterotoxin-producing $S$. aureus isolated from goat's milk (Foschino et al., 2002; da Silva et al., 2005), and skin of udder, teats, and milk (Valle et al., 1990). In sheep, goats, and cattle, sec was the predominant toxin type detected in $S$. aureus isolated from mastitic milk (Orden et al., 1992a,b). However, this is the first case of identification of an $S$. aureus strain from goat IMI with the sel encoding gene.

\section{Antimicrobial Susceptibility}

Table 5 shows the antimicrobial susceptibility (as $\mathrm{MIC}_{50}$ and $\mathrm{MIC}_{90}$ ) of 28 isolates of $S$. aureus collected from different animals throughout the lactation. All $S$. aureus isolates were negative for the $\beta$-lactamase production test. The $\beta$-lactams (penicillins and cephalosporins) are widely used for intramammary treatment of bovine IMI, and their use is rapidly increasing also for the control of IMI in small ruminants. We observed high efficacy in vitro of benzylpenicillin against $S$. aureus $\left(\mathrm{MIC}_{50}=0.025\right.$ and $\left.\mathrm{MIC}_{90}=0.1 \mu \mathrm{g} / \mathrm{mL}\right)$; only 2 
Table 4. Distribution panel of antimicrobial resistance (X) among 28 Staphylococcus aureus isolates.

\begin{tabular}{|c|c|c|c|c|c|c|c|c|c|c|c|}
\hline Isolate & $\mathrm{PEN}^{1}$ & $\mathrm{AMP}$ & AMX & $\mathrm{AMC}$ & CLX & $\mathrm{KAN}$ & OT & DOX & CFP & $\mathrm{CPH}$ & LIN \\
\hline 1 & & X & X & & & $\mathrm{X}$ & $\mathrm{X}$ & $X$ & & & $\mathrm{X}$ \\
\hline 2 & & X & X & & & $X$ & $X$ & X & & & $\mathrm{X}$ \\
\hline 3 & & X & $\mathrm{X}$ & & & & $\mathrm{X}$ & $X$ & & & $\mathrm{X}$ \\
\hline 4 & & & $\mathrm{X}$ & & & & $X$ & X & & & \\
\hline 5 & & $\mathrm{X}$ & $\mathrm{X}$ & & & & $\mathrm{X}$ & $\mathrm{X}$ & & & \\
\hline 6 & X & X & $X$ & & & $\mathrm{X}$ & $X$ & X & & & $X$ \\
\hline 7 & & & $X$ & & & $\mathrm{X}$ & $\mathrm{X}$ & $\mathrm{X}$ & & & \\
\hline 8 & & & $\mathrm{X}$ & & & & $X$ & X & & & \\
\hline 9 & & & & & & & $\mathrm{X}$ & $\mathrm{X}$ & & & $X$ \\
\hline 10 & & & X & & & & $\mathrm{X}$ & $\mathrm{X}$ & & & \\
\hline 11 & & $X$ & $X$ & & & & $X$ & $\mathrm{X}$ & & & $X$ \\
\hline 12 & & $X$ & $\mathrm{X}$ & & & & $\mathrm{X}$ & & & & $\mathrm{X}$ \\
\hline 13 & & & $X$ & & & & $X$ & X & & & $X$ \\
\hline 14 & & & $\mathrm{X}$ & & & & $\mathrm{X}$ & $X$ & & & \\
\hline 15 & & & $X$ & & & & $X$ & X & & & \\
\hline 16 & & & & & & & $X$ & X & & & \\
\hline 17 & & X & & & & & $X$ & X & & & $X$ \\
\hline 18 & & X & $\mathrm{X}$ & & & $X$ & $X$ & $\mathrm{X}$ & & & $X$ \\
\hline 19 & & $\mathrm{X}$ & $\mathrm{X}$ & & X & & $X$ & $X$ & & & $X$ \\
\hline 20 & & $\mathrm{X}$ & $X$ & & & $X$ & $X$ & X & & & $X$ \\
\hline 21 & & $X$ & & & & & $\mathrm{X}$ & $X$ & & & $\mathrm{X}$ \\
\hline 22 & & X & $X$ & & & & $X$ & $\mathrm{X}$ & & & $X$ \\
\hline 23 & & $X$ & $\mathrm{X}$ & & & & $\mathrm{X}$ & $X$ & & & $\mathrm{X}$ \\
\hline 24 & & X & & & & & $X$ & X & & & $X$ \\
\hline 25 & & $\mathrm{X}$ & $\mathrm{X}$ & & & & $X$ & X & & & $X$ \\
\hline 26 & X & $X$ & $\mathrm{X}$ & & & $\mathrm{X}$ & $\mathrm{X}$ & & & & $\mathrm{X}$ \\
\hline 27 & & $\mathrm{X}$ & $\mathrm{X}$ & & $\mathrm{X}$ & $\mathrm{X}$ & $\mathrm{X}$ & & & & \\
\hline 28 & & $X$ & $\mathrm{X}$ & & & $\mathrm{X}$ & $\mathrm{X}$ & $\mathrm{X}$ & & & \\
\hline
\end{tabular}

${ }^{1} \mathrm{PEN}=$ Benzylpenicillin, $\mathrm{AMP}=$ ampicillin, AMX = amoxicillin, AMC = amoxicillin plus clavulanic acid, CLX = cloxacillin, KAN = kanamycin, OT $=$ oxytetracycline, $\mathrm{DOX}=$ doxycycline, $\mathrm{CFP}=$ cephoperazone, $\mathrm{CPH}=$ cephalonium, and LIN = lincomycin.

isolates were resistant to this drug. In the penicillin group, cloxacillin showed strong activity, as $\mathrm{MIC}_{90}$ was $0.5 \mu \mathrm{g} / \mathrm{mL}$. The combination of amoxicillin plus clavulanic acid had similar effects on $S$. aureus $\left(\mathrm{MIC}_{90}=0.5\right.$ $\mu \mathrm{g} / \mathrm{mL}$ ), and all isolates were susceptible. Ampicillin

Table 5. Antimicrobial susceptibility of strains of Staphylococcus aureus isolated from different animals throughout the lactation.

\begin{tabular}{llccl}
\hline & Breakpoint & $\mathrm{MIC}_{50}{ }^{2}$ & $\mathrm{MIC}_{90}$ & Range \\
\cline { 2 - 5 } & & \multicolumn{4}{c}{$(\mu \mathrm{g} / \mathrm{mL})$} & \\
\cline { 2 - 5 } PEN $^{1}$ & $\geq 0.25$ & 0.025 & 0.1 & 0.0016 to 0.5 \\
AMP & $\geq 0.5$ & 0.5 & 1 & 0.1 to 8 \\
AMX & $\geq 0.5$ & 0.5 & 1 & 0.25 to 2 \\
AMC & $\geq 8$ & 0.25 & 0.5 & 0.25 to 1 \\
CLX & $\geq 4$ & 0.25 & 0.5 & 0.1 to 32 \\
CPH & $\geq 32$ & 0.1 & 0.1 & 0.05 to 1 \\
CFP & $\geq 64$ & 1 & 2 & 0.5 to 8 \\
OT & $\geq 16$ & $>500$ & $>500$ & 250 to $>500$ \\
DOX & $\geq 16$ & 250 & 250 & 0.5 to 250 \\
KAN & $\geq 64$ & 15 & $>500$ & 8 to $>500$ \\
LIN & $\geq 4$ & 7.5 & 31.2 & 1 to 64 \\
\hline
\end{tabular}

${ }^{1} \mathrm{PEN}=$ Benzylpenicillin, $\mathrm{AMP}=$ ampicillin, AMX = amoxicillin, $\mathrm{AMC}=$ amoxicillin plus clavulanic acid, $\mathrm{CLX}=$ cloxacillin, $\mathrm{CPH}=$ cephalonium, $\mathrm{CFP}=$ cephoperazone, $\mathrm{OT}=$ oxytetracycline, $\mathrm{DOX}=$ doxycycline, $\mathrm{KAN}=$ kanamycin, and LIN = lincomycin.

${ }^{2} \mathrm{MIC}_{50}$ and $\mathrm{MIC}_{90}$ are the minimum concentrations of the various antimicrobial agents required to inhibit growth of 50 and $90 \%$ of the isolates tested, respectively. and amoxicillin alone showed lower efficacy against $S$. aureus, as $\mathrm{MIC}_{50}$ and $\mathrm{MIC}_{90}$ were greater than the breakpoint value; only 8 and 5 isolates, respectively, were susceptible to these drugs. However, although the $\mathrm{MIC}_{90}$ value for ampicillin was greater than the $0.5 \mu \mathrm{g} /$ $\mathrm{mL}$ level that is used to categorize staphylococci as being resistant to this compound (NCCLS, 2002), this value was much lower than the $\mathrm{MIC}_{90}$ value found for $S$. aureus isolated from bovine IMI that were positive for $\beta$-lactamase (Watts and Salmon, 1997). In that study, the ampicillin $\mathrm{MIC}_{90}$ values for $S$. aureus isolates that were negative and positive for $\beta$-lactamase were 0.5 and $4.0 \mu \mathrm{g} / \mathrm{mL}$, respectively.

The resistance displayed by most of the isolates against ampicillin and amoxicillin, despite the negative $\beta$-lactamases test, could be explained by different mechanisms of resistance induced by misuse of these drugs. It has been demonstrated (de Oliveira et al., 2000) that some $S$. aureus strains produce low amounts of $\beta$-lactamases but exhibit an inducible expression in the presence of antibiotics.

The cephalosporins are usually classified into different generations on the basis of their antimicrobial spectrum. Globally, there are intramammary formulations of 5 first-generation cephalosporins (cefazolin, cepha- 
lexin, cephalotin, cephalonium, and cephapirin), $1 \mathrm{~s}-$ generation cephalosporin (cefuroxime), and 1 third-generation cephalosporin (cephoperazone) to treat mastitis in dairy ruminants. In the present study, cephalonium and cephoperazone were included as first- and thirdgeneration drugs, respectively. Against the $S$. aureus isolated, cephalonium and cephoperazone showed good activity $\left(\mathrm{MIC}_{90}=0.1 \mu \mathrm{g} / \mathrm{mL}\right.$ and $\mathrm{MIC}_{90}=2 \mu \mathrm{g} / \mathrm{mL}$, respectively), and all isolates were susceptible to these drugs. Lincomycin, kanamycin, and oxytetracycline (selected as representative drugs of the macrolide, aminoglycoside, and tetracycline groups, respectively) showed poor activity against $S$. aureus tested in the present study, as $\mathrm{MIC}_{90}$ were greater than breakpoint values.

According to the molecular typing results, all isolates seemed to belong to one clone of $S$. aureus, but differences in phenotypic resistance patterns were found ( $\mathrm{Ta}$ ble 5). Interestingly, some studies have reported that antimicrobial resistance did not appear to be a marker that always spreads clonally through a herd (Goni et al., 2004; Sabour et al., 2004), and this observation was also confirmed in the present study. The resistance genes identified in $S$. aureus are located on plasmids or mobile genetic elements (Kuroda et al., 2001). Acquisition of resistance involves transfer of resistance genes by some form of genetic exchange (conjugation, transduction, or transformation) from another organism, including bacteria of the same or different staphylococcal species and other gram-positive bacteria (Werckenthin et al., 2001).

\section{CONCLUSIONS}

Subclinical IMI by $S$. aureus in goats was associated with a significant increase in SCS relative to uninfected animals ( 7.55 vs. 5.50). Uninfected udder halves of infected goats had lower SCS than infected halves of the same goat, but higher SCS than that from goats that were free from infection throughout the study. No significant difference in milk yield or percentages of fat and protein were observed between healthy and infected goats. Based on these results, one cannot justify treatment of chronic subclinical IMI infections by $S$. aureus during the lactation, at least for the prevention of lost production. Dry treatment may be a better strategy to minimize the amount of milk that would be discarded because of antibiotic residues and to decrease the risk of antibiotic resistance from overuse of antimicrobial agents. The finding that antimicrobial resistance was different for $S$. aureus isolates and drugs tested, point out that one or a few isolates taken from a given site or animal will not necessarily represent the total antimicrobial resistance present in the herd. An investigation into the type and distribution of plas- mids encoding for antimicrobial resistance within both $S$. aureus and the general bacterial populations could determine the mode of inheritance of resistance and the relatedness of different molecular types. However, based on these observations, goat $S$. aureus isolated from this herd can still be treated effectively with the usual set of antibiotics available for intramammary therapy. Benzylpenicillin, amoxicillin plus clavulanic acid, cloxacillin, cephalonium, and cephoperazone can be considered the most suitable antimicrobial agents for therapeutic applications to eradicate, or at least reduce, $S$. aureus prevalence.

\section{ACKNOWLEDGMENTS}

We are thankful to the Provincial Breeding Association of Asti for technical assistance and R. Zadoks, M. J. Paape, and T. Grant for technical reading. This work was supported by the Fondazione Cariplo (Contract no. 159 2003.1824/10.8441) and by Italian FIRST 2004 (P. Moroni).

\section{REFERENCES}

Aarestrup, F. M., C. A. Dangler, and L. M. Sordillo. 1995. Prevalence of coagulase gene polymorphism in Staphylococcus aureus isolates causing bovine mastitis. Can. J. Vet. Res. 59:124-128.

Akineden, Ö., C. Annemüller, A. A. Hassan, C. Lämmler, W. Woler, and M. Zschöck. 2001. Toxin genes and other characteristics of Staphylococcus aureus isolates from milk of cows with mastitis. Clin. Diagn. Lab. Immunol. 8:959-964.

Bachmann, H. P., and U. Spahr. 1995. The fate of potentially pathogenic bacteria in Swiss hard and semihard cheeses made from raw milk. J. Dairy Sci. 78:476-483.

Bergonier, D., R. de Cremoux, R. Rupp, G. Lagriffoul, and X. Berthelot. 2003. Mastitis of dairy small ruminants. Vet. Res. 34:689-716

Contreras, A., J. C. Corrales, A. Sànchez, and D. Sierra. 1997. Persistence of caprine intramammary pathogens throughout lactation. J. Dairy Sci. 80:2815-2819.

Cremonesi, P., C. Vimercati, M. Luzzana, M. Brasca, S. Morandi, R. Lodi, P. Moroni, and B. Castiglioni. 2005. Development of multiplex PCR assay for the identification of Staphylococcus aureus enteritoxigenic strains isolated from milk and dairy products. Mol. Cel. Probes (accepted).

da Silva, E. R., L. S. do Carmo, and N. da Silva. 2005. Detection of the enterotoxins A, B, and C genes in Staphylococcus aureus from goat and bovine mastitis in Brazilian dairy herds. Vet. Microb. 106:103-107.

da Silva, E. R., A. P. Siqueira, J. C. Dias Martins, W. P. B. Ferreira, and N. da Silva. 2004. Identification and in vitro antimicrobial susceptibility of Staphylococcus species isolated from goat mastitis in the Northeast of Brazil. Small Rumin. Res. 55:45-49.

Davis, S. R., V. C. Farr, C. G. Prosser, G. D. Nicholas, S. Turner, J. Lee, and A. L. Hart. 2004. Milk L-lactate concentration is increased during mastitis. J. Dairy Res. 71:175-181.

de Oliveira, A. P., J. L. Watts, S. A. Salmon, and F. M. Aarestrup. 2000. Antimmicrobial susceptibility of Staphylococcus aureus isolated from bovine mastitis in Europe and United States. J. Dairy Sci. 83:855-862.

Deinhofer, M., and A. Pernthaner. 1995. Staphylococcus spp. as mastitis-related pathogens in goat milk. Vet. Microbiol. 43:161-166.

Dulin, M. A., M. J. Paape, W. D. Schultze, and B. T. Weinland. 1983. Effect of parity, stage of lactation, and intramammary infection 
on concentration of somatic cells and cytoplasmic particles in goat milk. J. Dairy Sci. 66:2426-2433.

Foschino, R., A. Invernizzi, R. Barucco, and K. Stradiotto. 2002. Microbial composition, including the incidence of pathogens, of goat milk from the Bergamo region of Italy during a lactation year. J. Dairy Res. 69:213-225.

Goni, P., Y. Vergara, J. Ruiz, I. Albizu, J. Vila, and R. Gomez-Lus. 2004. Antibiotic resistance and epidemiological typing of Staphylococcus aureus strains from ovine and rabbit mastitis. Int. J. Antimicrob. Agents 23:268-272.

Hookey, J. V., J. F. Richardson, and B. D. Cookson. 1998. Molecular typing of Staphylococcus aureus based on PCR restriction fragment length polymorphism and DNA sequence analysis of the coagulase gene. J. Clin. Microbiol. 36:1083-1089.

Kalogridou-Vassiliadou, D. 1991. Mastitis-related pathogens in goat milk. Small Rumin. Res. 4:203-212.

Kuroda, M., T. Ohta, I. Uchiyama, T. Baba, H. Yuzawa, I. Kobayashi, L. Cui, A. Oguchi, K. Aoki, Y. Nagai, J. Lian, T. Ito, M. Kanamori, H. Matsumaru, A. Maruyama, H. Murakami, A. Hosoyama, Y. Mizutani-Ui, N. K. Takahashi, T. Sawano, R. Inoue, C. Kaito, K. Sekimizu, H. Hirakawa, S. Kuhara, S. Goto, J. Yabuzaki, M. Kanehisa, A. Yamashita, K. Oshima, K. Furuya, C. Yoshino, T. Shiba, M. Hattori, N. Ogasawara, H. Hayashi, and K. Hiramatsu. 2001. Whole genome sequencing of methicillin-resistant Staphylococcus aureus. Lancet 357:1225-1240.

Lange, C., M. Cardoso, D. Senczek, and S. Schwarz. 1999. Molecular subtyping of Staphylococcus aureus isolates from cases of bovine mastitis in Brazil. Vet. Microb. 67:127-141.

Leitner, G., U. Merin, N. Silanikove, E. Ezra, M. Chaffer, N. Gollop, M. Winkler, A. Glickman, and A. Saran. 2004. Effect of subclinical intramammary infection on somatic cell counts, NAGase activity and gross composition of goats' milk. J. Dairy Res. 71:311-315.

Letertre, C., S. Perelle, F. Dilasser, and P. Fach. 2003. Identification of a new putative enterotoxin SEU encoded by the egc cluster of Staphylococcus aureus. J. Appl. Microbiol. 95:38-43.

Moroni, P., G. Pisoni, M. Antonini, G. Ruffo, S. Carli, G. Varisco, and P. J. Boettcher. 2005. Subclinical intramammary infection and antimicrobial susceptibility of Staphylococcus caprae and Staphylococcus epidermidis isolated from two Italian goat herds. J. Dairy Sci. 85:1694-1704.

National Committee for Clinical Laboratory Standards. 2002. Performance Standards for Antimicrobial Disk and Dilution Susceptibility Tests for Bacteria Isolated from Animals; Approved Standard Second Edition. Document M31-A2. NCCLS, Wayne, PA.

National Mastitis Council. 1999. Laboratory Handbook on Bovine Mastitis. Revised. National Mastitis Council Inc., Madison, WI.

Orden, J. A., J. Goyache, J. Hernandez, A. Domenech, G. Suarez, and E. Gomez-Lucia. 1992a. Applicability of an immunoblot technique combined with a semiautomated electrophoresis system for detection of staphylococcal enterotoxins in food extracts. Appl. Environ. Microbiol. 58:4083-4085.
Orden, J. A., J. Goyache, J. Hernandez, A. Domenech, G. Suarez, and E. Gomez-Lucia. 1992b. Detection of enterotoxins and TSST1 secreted by Staphylococcus aureus isolated from ruminant mastitis: Comparison of ELISA and immunoblot. Appl. Environ. Microbiol. 72:486-489.

Sabat, A., J. Krzyszton-Russjan, W. Strzalka, R. Filippek, K. Kosowska, W. Hryniewicz, J. Travis, and J. Potempa. 2003. New method for typing Staphylococcus aureus strains: Multiple-locus variablenumber tandem repeat analysis of polymorphism and genetic relationships of clinical isolates. J. Clin. Microb. 41:1801-1804.

Sabour, P. M., J. J. Gill, D. Lepp, J. C. Pacan, R. Ahmed, R. Dingwell, and K. Leslie. 2004. Molecular typing and distribution of Staphy. lococcus aureus isolates in eastern Canadian dairy herds. J. Clin. Microbiol. 42:3449-3455.

Scherrer, D., S. Corti, J. E. Muehlherr, C. Zweifel, and R. Stephan. 2004. Phenotypic and genotypic characteristic of Staphylococcus aureus isolated from raw bulk-tank milk samples of goats and sheep. Vet. Microb. 101:101-107.

Schwarzkopf, A., and H. Karch. 1994. Genetic variation in Staphylococcus aureus coagulase genes: Potential and limits for use as epidemiological marker. J. Clin. Microb. 32:2407-2412.

Shopsin, B., M. Gomez, M. Waddington, M. Riehman, and B. N Kreiswirth. 2000. Use of the coagulase (coa) repeat region nucleotide sequences for typing methicillin-resistant Staphylococcus aureus strains. J. Clin. Microb. 38:3453-3456.

Sommerhäuser, J., B. Kloppert, W. Wolter, M. Zschöck, A. Sobiraj, and K. Failing. 2003. The epidemiology of Staphylococcus aureus infections from subclinical mastitis in dairy cows during a control programme. Vet. Microb. 96:91-102.

Straub, J. A., C. Hertel, and W. P. Hammes. 1999. A 23S rDNAtargeted polymerase chain reaction-based system for detection of Staphylococcus aureus in meat starter cultures and dairy products. J. Food Prot. 62:1150-1156.

Tenover, F. C., D. R. Arbeit, R. V. Goering, P. A. Mickelsen, B. E. Murray, D. H. Persing, and B. Swaminathan. 1995. Interpreting chromosomal DNA restriction patterns produced by pulsed-fieldgel electophoresis: Criteria for bacterial strain typing. J. Clin. Microb. 33:2233-2239.

Valle, J., E. Gomez-Lucia, S. Piriz, J. Goyache, J. A. Orden, and S. Vadillo. 1990. Enterotoxin production by staphylococci isolated from healthy goats. Appl. Environ. Microbiol. 56:1323-1326.

Watts, J. L., and S. A. Salmon. 1997. Activity of selected antimicrobial agents against strains of Staphylococcus aureus isolated from bovine intramammary infections that produce $\beta$-lactamase. J. Dairy Sci. 80:788-791.

Werckenthin, C., M. Cardoso, J. L. Martel, and S. Schwarz. 2001. Antimicrobial resistance in staphylococci from animals with particular reference to bovine Staphylococcus aureus, porcine Staphylococcus hyicus, and canine Staphylococcus intermedius. Vet. Res. 32:341-362. 